\title{
Is the decline of Burrowing Owls Speotyto cunicularia in prairie Canada linked to changes in Great Plains ecosystems?
}

\author{
KORT M. CLAYTON and JOSEF K. SCHMUTZ
}

\begin{abstract}
Summary
We examined population and ecosystem patterns hoping to inform conservation strategies for Burrowing Owls Speotyto cunicularia in Canada. The owls chose moderately to heavily grazed grasslands for nesting and roosting, and avoided cultivated fields. Where grassland patches were isolated in $90 \%$ cultivation, owls dispersed later, for shorter distances and less often. Mortality rate during the 5-month study was high (adult ratio 0.45 , juveniles 0.55 ), which may contribute to local declines. Additional mortality may occur on migration and during winter. We extrapolate from local effects (loss of grassland habitat with burrows for roosting, and $2 \%$ "incidental" predation) to suggest that such changes detrimental to the owls occur throughout the central Great Plains ecosystem which the owls occupy year-round. The changes include ecosystem processes such as plant succession, owl dispersal and predation. These changes are likely to be irreversible on a scale that would be required to help this owl. The species may face extinction in Canada, at the northern limit of its range.
\end{abstract}

\section{Introduction}

In Canada, Burrowing Owls Speotyto cunicularia have declined in numbers and their range has become restricted throughout the four western provinces (Figure 1; Wellicome and Haug 1995). The owls are apparently extirpated in Manitoba and maintained through releases in British Columbia. The Committee on the Status of Endangered Wildlife in Canada classified Burrowing Owls as threatened in 1978 (Wedgwood 1978) and endangered in 1995 (Wellicome and Haug 1995).

The conservation status of Burrowing Owls varies throughout their U.S. range. The Florida population has expanded its range in recent decades in response to human alteration of the landscape (Ligon 1963). Western U.S. populations are listed as 'endangered' in two states (Minnesota and Iowa) or a 'species of special concern' (in California, Oregon, Washington, Montana, Wyoming, North Dakota). King (1996) described Burrowing Owls as "locally abundant" in southwestern Idaho where a change from sagebrush steppe to grassland may have benefited this species (King 1996, Knapp 1996).

Habitat fragmentation was negatively correlated with persistence of breeding Burrowing Owls in Saskatchewan (Warnock 1997). Owls using small isolated fragments may be more vulnerable to predation. Mammalian predators (i.e. 


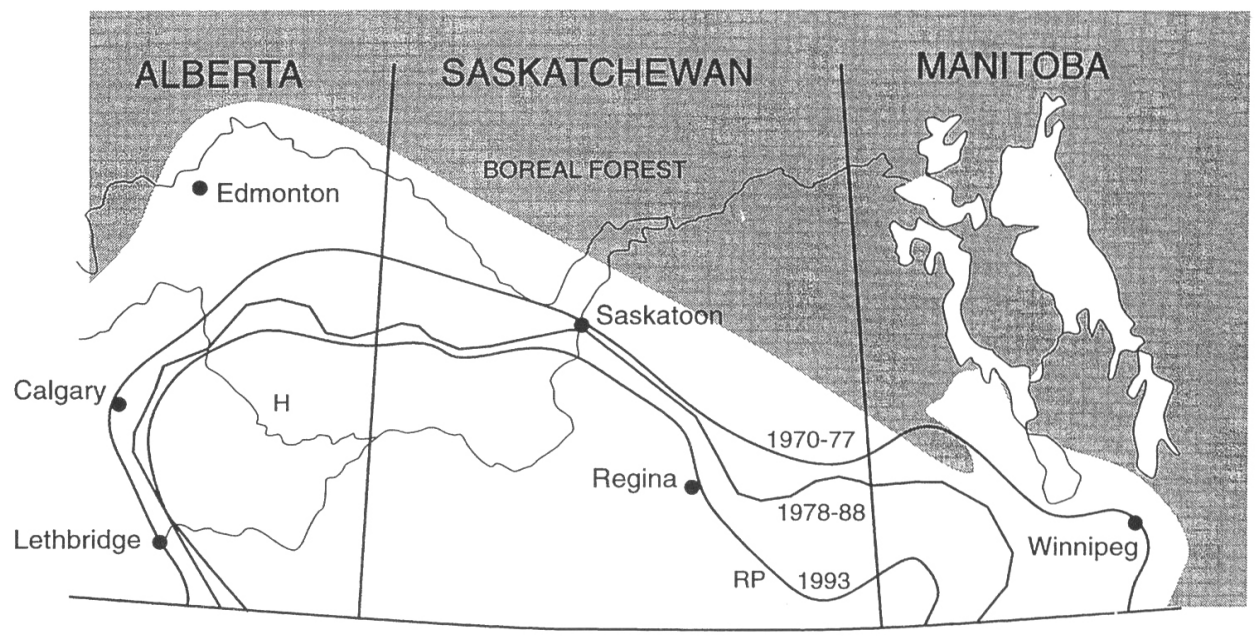

Figure 1. Diminution in the breeding range of Burrowing Owls in Canada is shown since 1970. The locations of the Hanna (H) and Regina Plains (RP) study areas are shown.

coyote Canis latrans and red fox Vules vulpes) can forage more efficiently in fragmented habitats with increased cover and habitat edge (e.g. Pasitschniak-Arts and Messier 1996). Insecticides can suppress prey populations and may have toxicological implications for Burrowing Owls (Fox et al. 1989, James and Fox 1987, James et al. 1990).

Management efforts that are currently implemented to protect Burrowing Owls in Canada include the organization of a national recovery team, a species conservation programme by landowners (Hjertaas 1997), phasing out the insecticide carbofuran, installation of artificial nest boxes, supplemental feeding, and captive breeding. While these actions have apparently slowed the decline, they have not reversed it. We suspect that the decline resulted from large-scale manipulation of the prairie landscape and disrupted ecological processes.

This study was designed in collaboration with the Canadian Burrowing Owl Recovery Team (Committee on the Recovery of Nationally Endangered Wildlife in Canada - RENEW; Anonymous 1995a) to examine broad spectrum population and ecosystem parameters including habitat use, dispersal, survival and timing of migration.

\section{Study areas}

One study site was located in south-eastern Alberta (Figure 2) near Sunnynook, south-east of the town of Hanna. This area was used for ranching with less than $20 \%$ of the land under cultivation (Schmutz et al. 1980, Anonymous 1988). Annual precipitation averaged $27 \mathrm{~cm}$ (Strong and Leggat 1992). Vegetation was dominated by the grasses, Stipa comata and Bouteloua gracilis (Smoliak et al. 1988, Strong and Leggat 1992). This region has a unique agricultural and biological history. Necessitated by soil erosion and farm breakdown, public land ownership and 


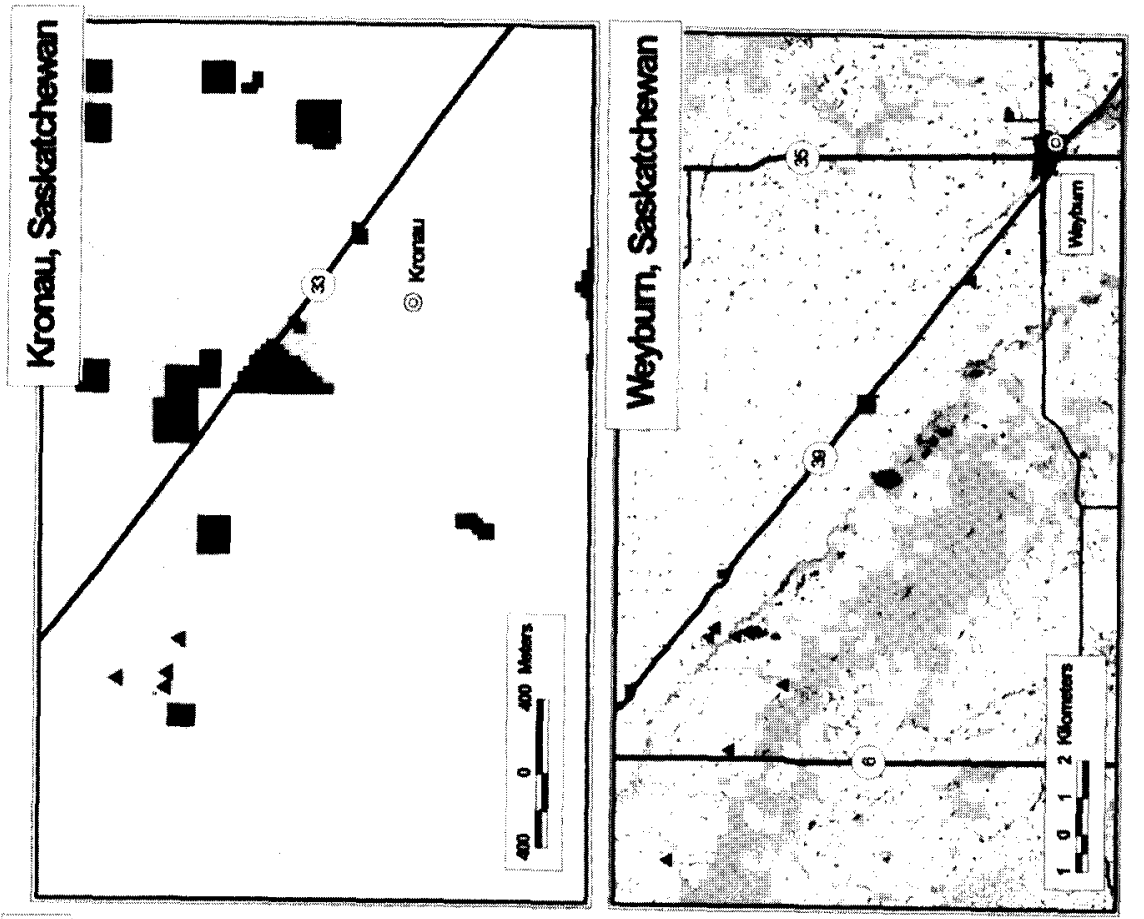

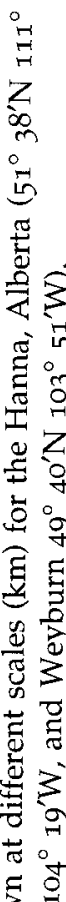
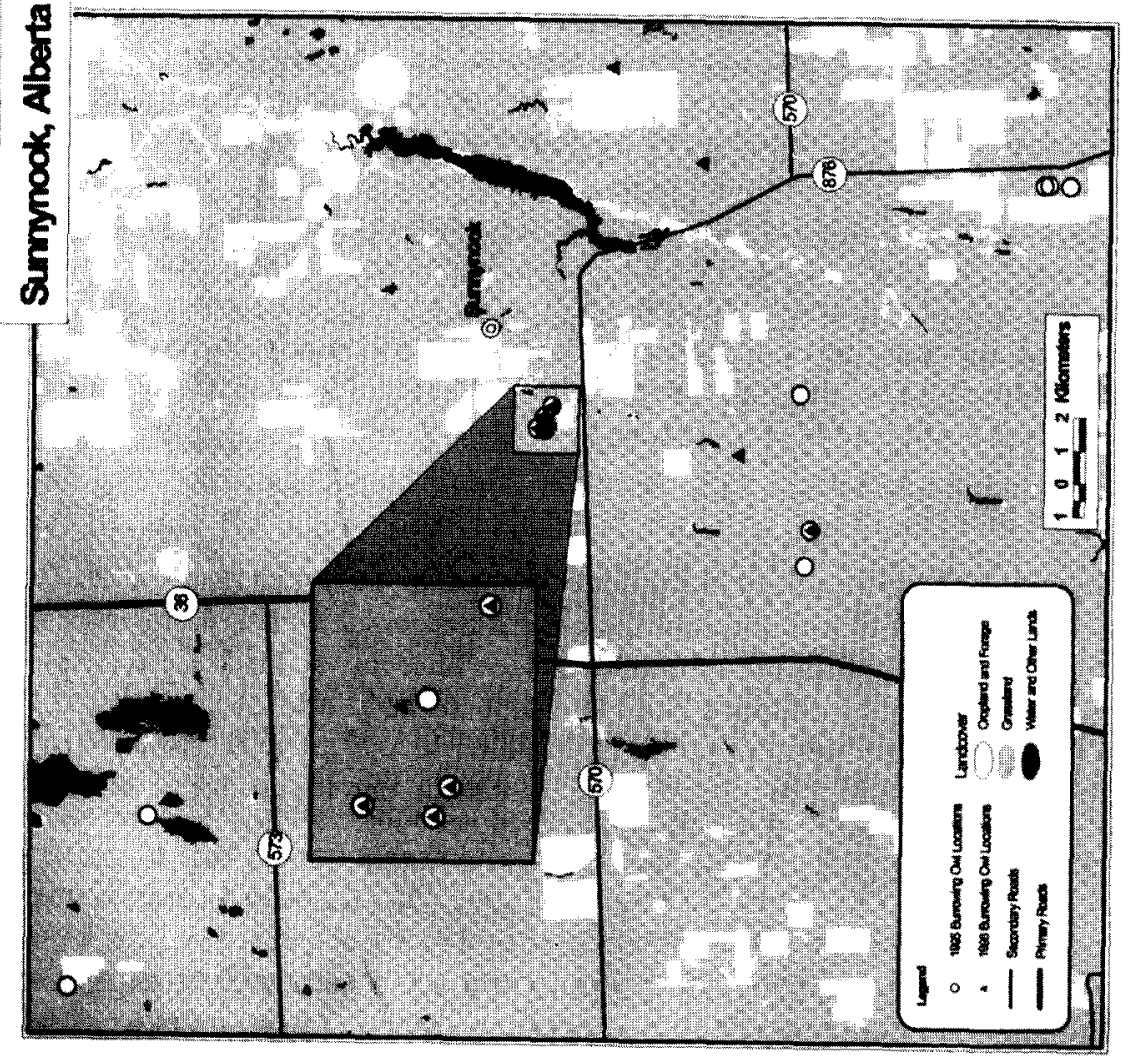

至

का

흥요

苛

完

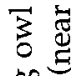

b

旅

క气

$\overrightarrow{\mathscr{V}}$

它焉

实吉

$\Xi$ 胥

窇

్ㅗㄹ

它

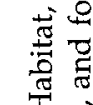

焉

$\stackrel{\pi}{5}$

点 
special municipal governance helped restore the land and revive a viable ranching community (Gorman 1988).

In its second year this study included the Regina Plain in south-eastern Saskatchewan, near Weyburn and Kronau (Figure 2). This region has productive agricultural soils (lacustrine clays) and approximately 90\% of the land produced cereal, oilseed and pulse crops (Anonymous 1988). Average annual precipitation exceeded $38 \mathrm{~cm}$. The remnant native grassland community was dominated by the grasses Agropyron dasystachyum and Koeleria cristata.

\section{Methods}

\section{Monitoring schedule and telemetry procedures}

Burrowing Owls were trapped near the nest from late incubation onwards in Alberta, using bal-chatris and noose carpets (Bloom 1987). Capturing owls by hand in artificial nest boxes in Saskatchewan facilitated slightly earlier radiomarking of juveniles, but never before they were older than 20 days.

Both adults and juveniles were equipped with aluminium Canadian Wildlife Service rings and plastic colour rings and were weighed, and measured. We used 4-g, necklace-style radio transmitters (Holohil Systems, Woodlawn, Canada; or Merlin Systems, Meridian, U.S.A.).

Each radio-tagged owl was checked daily when possible using hand-held, vehicle-mounted, or aircraft-mounted antennae. Homing in on an individual on foot yielded location accuracy not achievable from the air or by triangulation.

Aerial tracking was done from small aircraft with "side-looking' 3-element Yagi antennae mounted on the wing struts (Kenward 1987). Moderate signal strength permitted search patterns to be flown at about $1500 \mathrm{~m}$ above ground, where signal detection was up to $12 \mathrm{~km}$.

After owls dispersed from the immediate nest area, they typically centred their activities on a new roost-burrow complex. Little nocturnal monitoring was done; however, diurnal observations revealed bouts of loafing and insect hunting in the vicinity of the new roost burrow. This short-term fidelity to roost burrows prompted us to consider the burrow vicinity, rather than specific daily locations, as the sampling unit for dispersal movements and habitat use.

\section{Movements}

We defined first dispersal as displacement of $\geq 500 \mathrm{~m}$ from the nest for $\geq 2$ days, including migration if it was the first long-term dispersal. Subsequent relocation to a distinct burrow $\geq 250 \mathrm{~m}$ away was classified as a move. Final local dispersal was defined as the linear distance from the nest to the last known roost location of an owl on the study area prior to migration. When an owl disappeared in early autumn and could not be relocated with an extensive aerial search we assumed that the bird had initiated migration.

\section{Survival}

The small size and approximately 5 -month life span required of transmitters for this project precluded mortality sensors. Detection of mortalities was facilit- 
ated by attentive fieldwork. The proximate cause of death was broadly categorized based on the recovery location, condition of feather remains (chewed or plucked), and, if present, the weight and condition of the carcass (Einarsen 1956, Hamerstrom 1972).

To test the effect of transmitters on survival we observed the activities at each nest in 1995 in Alberta for 15 minutes every second day, from late pre-fledging until all or most individuals had dispersed (1-2 months).

\section{Habitat assessment}

Habitat preferences were interpreted from measurements taken around nest burrows, roost burrows, and random sites. Assessment included 16 vegetation height-density measurements taken with a "Robel stick" (Robel et al. 1970), litter depth, shrub cover, range condition (Smoliak et al. 1988, Wroe et al. 1988), and land use. Two Robel stick measurements were taken in opposing directions at points $10 \mathrm{~m}$ and $50 \mathrm{~m}$ from the nest or roost burrow in four cardinal directions. For random sites, these points were $25 \mathrm{~m}$ and $75 \mathrm{~m}$ from a point judged to be the centre of the pasture $(65 \mathrm{ha})$. Land use was classified as either cultivation, native pasture, or pasture re-seeded with Eurasian perennial grasses.

The Robel technique was not used in 1995 on the Hanna study area. Instead grass height was measured at three random locations within $100 \mathrm{~m}$ of the roost or nest burrow. By using a correction factor derived from 10 measurements we transformed the 1995 vegetation measurements taken with a ruler into Robel scores. Because the Robel technique accounts for vegetation density as well as height, the strict height measurements averaged $40 \%$ greater than comparable Robel scores.

We did not re-measure habitat variables when an owl was recorded in the same roost. Instead, $n$ was inflated to reflect the number of days one or several owls were recorded at each measured site. We assumed that our minimum I-day interval maintained statistical independence of observations despite re-use of measurements (White and Garrott 1990). Occupancy of the nest site late in the season (1o days beyond the mean date of first local dispersal by juveniles and adult males) or after dispersal, was recorded as roosting habitat.

The availability of different habitat categories was estimated through random sampling (White and Garrott 1990). We based this sampling on quarter sections (65 ha) because these units are readily identifiable and often homogeneous in cultivation or grazing pressure. We chose 1o quarter sections from 10 evenly spaced sections in each of several townships encompassing the study nests. Using this strategy, we effectively sampled $7 \%$ (by extrapolating from the small sampling plot to the homogeneous quarter-section) of the land area within the home range and dispersal range of Burrowing Owls on both study areas.

The prevalence of cultivation on the Regina Plain necessitated more sampling to achieve an adequate sample of grassland plots for analysis of vegetation characteristics. In this highly fragmented landscape fewer pastures comprised a full quarter-section. Consequently, any fragment of grassland exceeding 2 ha was sampled and we weighted the frequency value for each habitat category by its respective average acreage.

Random sampling for habitat availability was done separately for Alberta and 
Saskatchewan in 1996. However, the 1996 Alberta availability data were also used for comparison with 1995 habitat use in Alberta. We justified this comparison of use and availability from different years on two assumptions. First, land use, stocking rates and seasonal stock rotations are quite consistent in this area. This practice results in relatively consistent range condition from year to year. Second, even in the event of altered grazing pressure, the generally dry climate contributes to slow changes in the range condition and vegetation structure.

We used a chi-square distribution to test for differences in use and availability among habitat categories. Where $\chi^{2}$ was significant, $90 \%$ simultaneous confidence intervals were calculated following Marcum and Loftsgaarden (1980) to determine preference or avoidance of each habitat class (Byers and Steinhorst 1984).

\section{A demographic model}

To explore the potential influence of mortality in a local population decline, we used a simple demographic model to predict the annual rate of population change (k) from estimates of productivity and survival (Brooks and Temple 1990, James et al. 1997). Assumptions for this model included equivalent immigration and emigration, equivalent survival rates of males and females ( $1: 1$ sex ratio), and that all adults in the population are breeding. We assumed one clutch per female per year, because the rare observations of two clutches per female (Haug et al. 1993) may not apply to our population.

Animals were cared for in the field according to the traditional practice among field biologists, and this was approved each year by a local Animal Care Committee.

\section{RESULTS}

\section{Transmitter effects}

Wearing radio transmitters (e.g. Foster et al. 1992) could influence Burrowing Owls more than many other birds because the owls are small and inhabit burrows. We compared the survival of radio-marked and unmarked owls near Hanna in 1995 prior to fledging. Beyond this time we could no longer distinguish between departed unmarked owls and dead ones. Our cut-off date differed among nests (mean $=17$ August $\pm_{1} 5$ days). Using simple ratio survival estimates (survivors/total) for this portion of the study only, we recorded $89 \%$ survivors among 9 adults with, and $87 \%$ among 16 adults without transmitters. Survival was $67 \%$ for 12 radio-tagged juveniles and $70 \%$ for 30 untagged juveniles. A few owls were resighted the following year, including $29 \%$ of 7 radio-tagged adults and $8 \%$ of 12 of leg-ringed adults.

The interval from radio-marking to death was 29 days $\left( \pm_{14}\right)$ for Hanna in 1995 and 7 days $\left( \pm_{4}\right)$ in 1996, and 36 days $\left( \pm_{22}\right)$ on the Regina Plains in 1996. We believe, therefore, that transmitters did not have a prolonged influence on the owls' behaviour or their survival.

\section{Survival and cause-specific mortality}

Survival and cause-specific mortality estimates were generated for each of three time periods; pre-fledging, post-fledging dependency, and post-juvenile dis- 


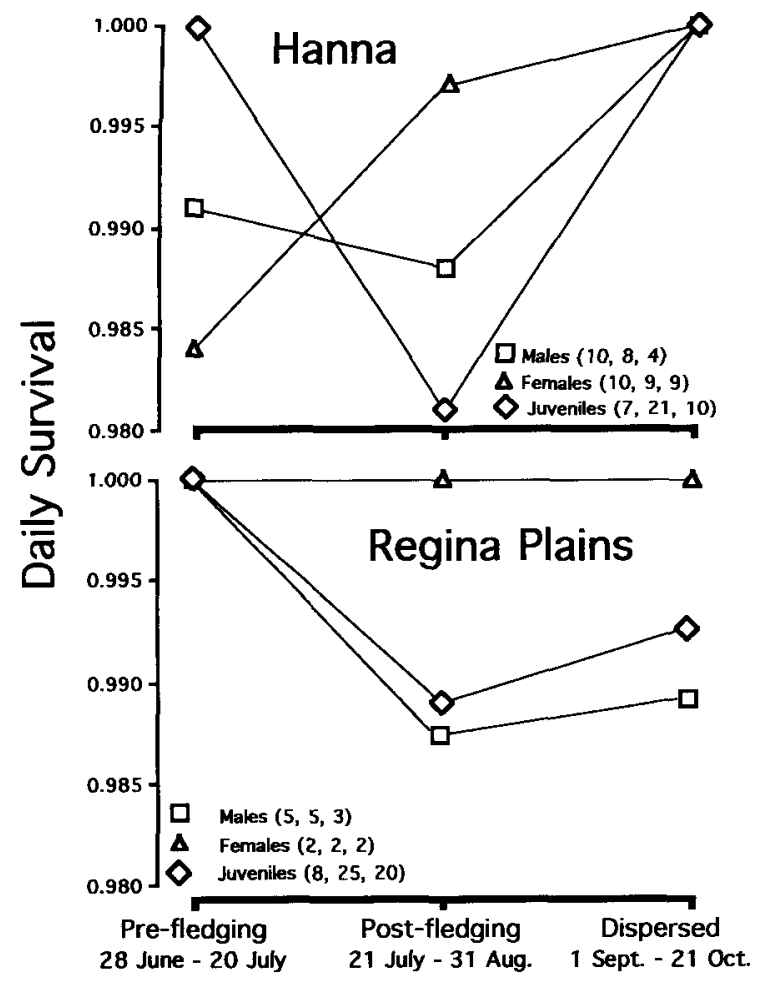

Figure 3. Daily survival rates of Burrowing Owls during three consecutive periods on the Hanna, Alberta, and Regina Plain, Saskatchewan study areas.

persal, using Micromort software (Heisey and Fuller 1985). These intervals were defined by nest chronology and juvenile behaviour using estimated fledging dates and mean juvenile dispersal dates. Daily survival rates varied during the three periods (Figure 3), and overall, were lowest during the post-fledging period when juvenile owls were capable of flight but still largely dependent on their parents.

Mortality sources were only broadly categorized (Table I). We attribute the

Table 1. Ratios of survival and cause-specific mortality for adult and juvenile Burrowing Owls near Hanna, Alberta, and on the Regina Plain, Saskatchewan

\begin{tabular}{|c|c|c|c|c|c|c|}
\hline \multirow[t]{2}{*}{ Age/Sex } & \multirow[t]{2}{*}{$n$} & \multirow[t]{2}{*}{ Survival } & \multicolumn{4}{|c|}{ Cause-specific mortality } \\
\hline & & & Raptors & Mammals & Vehicles & Other \\
\hline \multicolumn{7}{|c|}{ Hanna (28 June-21 Oct. 1995 and 1996) } \\
\hline Adult males & 11 & $0.4^{8}$ & 0.52 & o & 0 & o \\
\hline $\begin{array}{l}\text { Adult } \\
\text { Females }\end{array}$ & 12 & 0.62 & 0.23 & o & o & 0.15 \\
\hline Juveniles & 21 & 0.45 & 0.30 & 0.25 & o & o \\
\hline \multicolumn{7}{|c|}{ Regina Plain (25 June-17 Oct. 1996) } \\
\hline Adult Males & 5 & 0.38 & o & 0.18 & 0.18 & 0.26 \\
\hline $\begin{array}{l}\text { Adult } \\
\text { Females }\end{array}$ & 2 & 1.00 & 0 & o & o & 0 \\
\hline Juveniles & 25 & 0.48 & 0.08 & 0.10 & 0.17 & 0.17 \\
\hline
\end{tabular}


Table 2. The influence of varying survival rates on the population rate of change (lambda) is shown for a declining population of Burrowing Owls near Hanna, Alberta, raising an average of 3.5 young. $\mathrm{k}=($ adult survival $)+($ juvenile + survival fecundity $/ 2)$

\begin{tabular}{lcc}
\hline Adult survival & Juvenile survival & Lambda \\
\hline $0.55^{a}$ & $0.45^{a}$ & 1.34 \\
0.48 & 0.30 & 1.00 \\
0.34 & 0.19 & $0.67^{a}$ \\
\hline
\end{tabular}

${ }^{a}$ Values observed on the study area.

majority of the raptor kills to Swainson's Hawks Buteo swainsoni because (i) Swainson's Hawks are the most abundant raptor, (ii) we recovered several burrowing owl leg bands and transmitters from Swainson's hawk nests, (iii) we flushed a Swainson's hawk from a fresh burrowing owl which it had presumably killed, and (iv) the presence of streaked excrement at several of the burrowing owl kills indicates hawk rather than owl predation (owl faeces are not excreted forcefully). Only a few Burrowing Owls showed signs of falcon predation; e.g. meticulously plucked, wings cleanly bitten off, legs bones stripped of meat but not eaten.

Mammal-killed owls appeared to have been captured singly outside the burrow (not brood depredation within the burrow). This implicates a large, quick, stalking predator which is unable to enter the burrow, larger than badger Taxidea taxus, striped skunk Mephitis mephitis, weasel or mink Mustela spp. On the Alberta study area, at least, coyotes were more frequently observed and reported by local residents than red fox.

We used a simple demographic model, incorporating our own local estimates of mortality and reproduction, to examine the outcome for our population. Our fecundity estimate ( 3.5 young/nesting attempt) is an average for 324 observed nesting attempts over 11 years on the Hanna study area. Using our estimated ratios of adult and juvenile survival over a 5-month period ( 0.55 and 0.45 , respectively), and assuming, for a starting point, no further mortality during the rest of the year, the model suggested an increasing population (Table 2). Slightly lower survival rates caused the rate of population change to stabilize $(\sim 1)$. The estimated rate of decline for the Hanna population, $\mathrm{k}=0.67$, was achieved by lowering adult and juvenile survival rates further.

Results from burrowing owl surveys done in 1991, 1993, 1994, and 1997 in the Hanna, Alberta area suggest $\mathrm{k}=0.67$ (Caughley 1977, J. K. Schmutz and T. I. Wellicome unpublished data). To match this observed rate of decline, annual mortality of adults and juveniles may exceed our 5 month estimates only by a ratio of 0.21 and 0.26 , respectively. Thus, a large proportion of annual mortality occurs on the breeding grounds, and only about $32 \%$ may occur elsewhere.

\section{Habitat use}

We compiled indices of the combined vegetation height and density (Robel method) for both study areas in 1996 for a total of 88 "available" sites and 22 nests. We re-located 15 dispersing adult owls and 23 juveniles a total of 726 times 


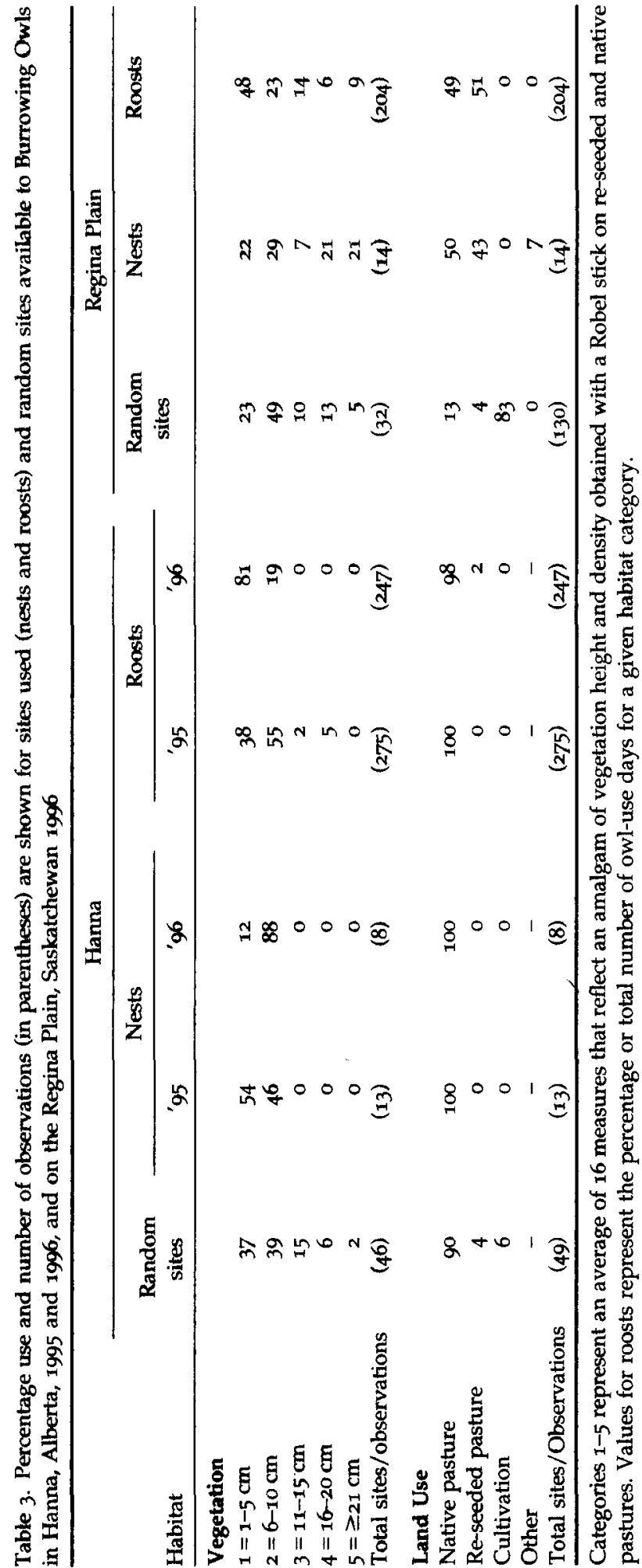


Table 4. Summary of chi-square analysis of habitat use in relation to availability for cases when the Burrowing Owls regularly used two or more categories (Table 3). The infrequent high Robel categories were collapsed

\begin{tabular}{|c|c|c|c|c|c|c|}
\hline & \multicolumn{3}{|c|}{ Hanna $1995^{-96}$} & \multicolumn{3}{|c|}{ Regina } \\
\hline & $x^{2}$ & d.f. & $p$ & $x^{2}$ & d.f. & $p$ \\
\hline \multicolumn{7}{|c|}{ Vegetation (Robel measure) } \\
\hline Nests & 6.64 & 2 & 0.036 & 1.94 & 2 & 0.379 \\
\hline Roosts & 36.30 & 2 & $<0.001$ & 7.81 & 3 & 0.050 \\
\hline \multicolumn{7}{|c|}{ Pasture type (Native vs. re-seeded) } \\
\hline Nests & & All nat & & 1.619 & 1 & 0.203 \\
\hline Roosts & & $98-100 \%$ & & 13.62 & 1 & $<0.001$ \\
\hline \multicolumn{7}{|c|}{ Land use (Cultivation, native and re-seeded pasture) } \\
\hline Nests & & All pas & & 46.24 & 2 & $<0.001$ \\
\hline Roosts & & All pas & & 280.82 & 2 & $<0.001$ \\
\hline
\end{tabular}

in Alberta and Saskatchewan (Table 3). These measures are a good indication of the habitat frequented by owls, at least during daytime, and reflect a combination of choice by the owls and the constraints faced by burrowing mammals (mostly Richardson's ground squirrels Spermophilus richardsonii, and badgers). Given the prevailing land uses in the two study areas, our samples allowed us to examine the owls' responses to vegetation height in Alberta, and vegetation height and land use (pasture vs. cultivation) in Saskatchewan.

As is generally the case on the Great Plains, owls in Saskatchewan preferred pastures (native or re-seeded comprising $16 \%$ of local land area) over cultivation for nesting and after fledging (Table 4 ). Re-seeded pastures were selected over native pastures for roosting in proportion to their respective availability. Within pastures, owls selected shorter grass for both nesting and roosting in both provinces (Table 5). Placing these results in the context of the owls' natural history, we suggest that grassland provides the requisite food resources and escape habitat (burrows, see below), and short grass provides visibility.

\section{Timing and distance of dispersal movements}

Juvenile owls in Alberta dispersed significantly earlier (Mann-Whitney $U=24.5$, $P=0.012)$, moved more frequently $(U=126, P<0.001)$, and ultimately dispersed

Table 5. Habitat selection exhibited by Burrowing Owls on the Hanna, Alberta, and Regina Plain, Saskatchewan, study areas

\begin{tabular}{|c|c|c|c|c|c|c|c|}
\hline & \multicolumn{4}{|c|}{ Vegetation } & \multicolumn{3}{|c|}{ Land use } \\
\hline & 1 & 2 & 3 & 4 & Native & Reseeded & Cultivated \\
\hline Hanna roosts & $\mathbf{P}$ & PU & A & - & & & \\
\hline Hanna nests & PU & PU & $\mathrm{A}$ & - & & & \\
\hline Regina roosts & $\mathrm{P}$ & $\mathrm{A}$ & PU & PU & $\mathrm{P}$ & $\mathrm{P}$ & A \\
\hline Regina roosts & & & & & A & $\mathrm{P}$ & - \\
\hline Regina nests & & & & & $\mathrm{P}$ & $\mathrm{P}$ & A \\
\hline
\end{tabular}

Abbreviations represent preference (P), proportional use according to availability (PU) and avoidance (A) of vegetation categories and land use types including native pasture, re-seeded pasture and cultivated land. 
further from the nest $(U=18, P=0.004)$ than juveniles in Saskatchewan (Table 6). Movements by juveniles in Alberta also tended to be longer than those in Saskatchewan but this was not statistically significant $(U=145, P=0.173)$ (Table 6).

All owls in Alberta range lands could move $500 \mathrm{~m}$ in at least one direction from any nest or roost burrow and remain in grassland (Figure 2). These grasslands had burrow complexes scattered throughout well-drained soils. For example, a mean of 35.2 (range 4-70) ground squirrel and 5.7 (range $0-17$ ) badger-size burrows were counted on this study area on $2 \times 1,000 \mathrm{~m}$ transects centred on 27 systematically selected points, $1 \mathrm{~km}$ away from an occupied nest burrow (Schmutz 1997a). In contrast, radio-marked owls in the Saskatchewan area could make a move of $500 \mathrm{~m}$ without crossing cultivated land devoid of burrows less than $<10 \%$ of the time (Figure 2).

\section{Discussion}

\section{Habitat use}

The habitats occupied by Burrowing Owls in our study are consistent with other studies where owls occupied "dry, open, shortgrass, treeless plains, often associated with burrowing mammals" (Haug et al. 1993). Overall, the owls used areas of short vegetation preferentially for nesting and roosting. In the Alberta range lands, these shortgrass sites existed in a vegetation-height mosaic influenced by shrubs (Symphoricarpos, Eleagnus and Rosa sp.), by differences in drainage and soil moisture in a knoll and kettle terrain, and by cattle distribution (e.g. distance from drinking water) affecting grazing pressure and grass height. In the Saskatchewan crop lands, the notable difference was that the owls' nests were not selectively placed in short vegetation. We attribute this to a paucity of suitable habitat. Here owls also nested in the non-agriculturally used strips of medium to tall grass between fields and other features such as ponds, granaries and roads.

Although the owls favoured exposed sites for nesting and roosting and hunted at these sites on foot and on the wing, they also hunted over other areas utilizing perches, hovering and gleaning insects from tall vegetation (Haug and Oliphant 1990, Schmutz et al. 1991). Thus we consider the habitat mosaic an important element from a conservation point of view. Cricetid rodents may benefit from the food and cover provided by dense and tall vegetation (e.g. Bock et al. 1984), but be most vulnerable to the owls when traversing open sites. Also, patches of short grass may attract grasshoppers to the exposed soil oviposition sites (Dan Johnson, pers. comm. 1996) and this in turn may attract mice (Peromyscus sp.; Clayton 1997).

\section{Movements}

Before we interpret the dispersal data, we need to consider the potential impact of a feeding study carried out on the Regina Plain. As with other birds (Frumkin 1994), supplemental feeding can delay post-fledging dispersal in Burrowing Owls (King 1996). Although $77 \%$ of the Saskatchewan nests received supplemental food, we doubt that this confounded our results for two reasons. First, 


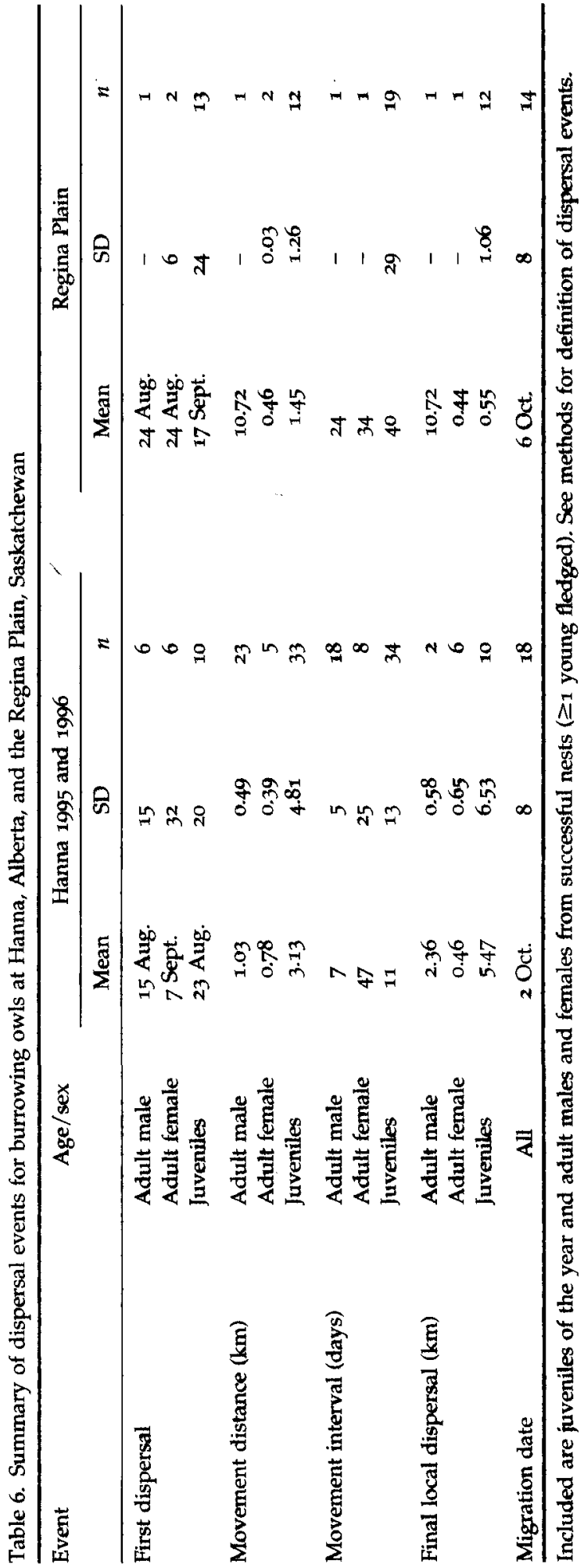


our owls were not fed after fledging ( $\sim 40$ days old). In King's (1996) study, Burrowing Owls were fed as long as they remained in their respective natal areas and these owls took advantage of the food source by moving less than a control group, in some cases as late as October. Second, the interval between fledging and dispersal when our owls were not fed, might adequately buffer the influence of supplemental food received earlier. This interval, although variable (Hanna $1995=39$ days, Hanna $1996=26$ days, Regina Plain $1996=49$ days), exceeded the length of King's unfed control group (21 days) in all cases.

We suggest, therefore, that the limited dispersal by Burrowing Owls on the Regina Plain is related to the highly fragmented agricultural landscape. Reduced availability of pastures on the Regina plain ( $\sim_{16 \%}$ of land area) may discourage dispersal from the natal area and reduce subsequent movements across the landscape. Delayed post-fledging dispersal has been described for Crested Tits Parus cristatus in highly fragmented landscapes (Lens and Dhondt 1994). By varying the number of habitat clusters and the spatial scale at which clustering occurs in their model, Doak et al. (1992) found that fragmentation can increase search time and reduce dispersal success.

\section{Owl survival}

Two conclusions with potential conservation implications emerged from the mortality data. First, most owls $(72 \%)$ were killed near the nest during the postfledging dependency period. The considerable activity around nests at that time may serve as a cue to predators. Second, the interesting differences in mortality between Alberta and Saskatchewan lie with the sources, not in the overall rates. Owls from the sparsely populated Hanna area were killed mostly by predators (94\%), and none by vehicles. In Saskatchewan, however, predators and vehicles killed about equal numbers ( $38 \%$ and $31 \%$, respectively). This extensively cultivated and highly fragmented landscape probably supports lower densities of buteonine hawks and canids than the Hanna region. However, increased vehicle traffic on the Regina Plain boosts overall mortality up to levels resulting from predation only in Alberta. Judging from data on migration routes and winter residency, the owls frequent a mix of habitats in the U.S. and possibly Mexican portions of the great plains. Thus the owls are likely to face mortalities yearround that are similar to those observed in our study (see below).

The results of our model, in which we compare our observed partial losses with data on reproduction, suggest that our population is threatened. Our mortality estimates covering a five-month period alone are so high, that only a further $7 \%$ and $15 \%$ mortality would be required for adults and juveniles, respectively, for mortality to equal reproduction. In all likelihood, mortality during the remaining 7 months, during which the owls have to migrate and establish winter territories, is also high. Thus, it is highly plausible that these and additional losses to be expected on migration and over winter may yield low annual survival. This may be low enough to explain the observed population declines. We know of no comparable data on burrowing owl mortalities.

\section{Ecosystem change}

Of the many factors that have been implicated in the Burrowing Owls' decline in Canada (Wellicome and Haug 1995), we have shown an influence of habitat 


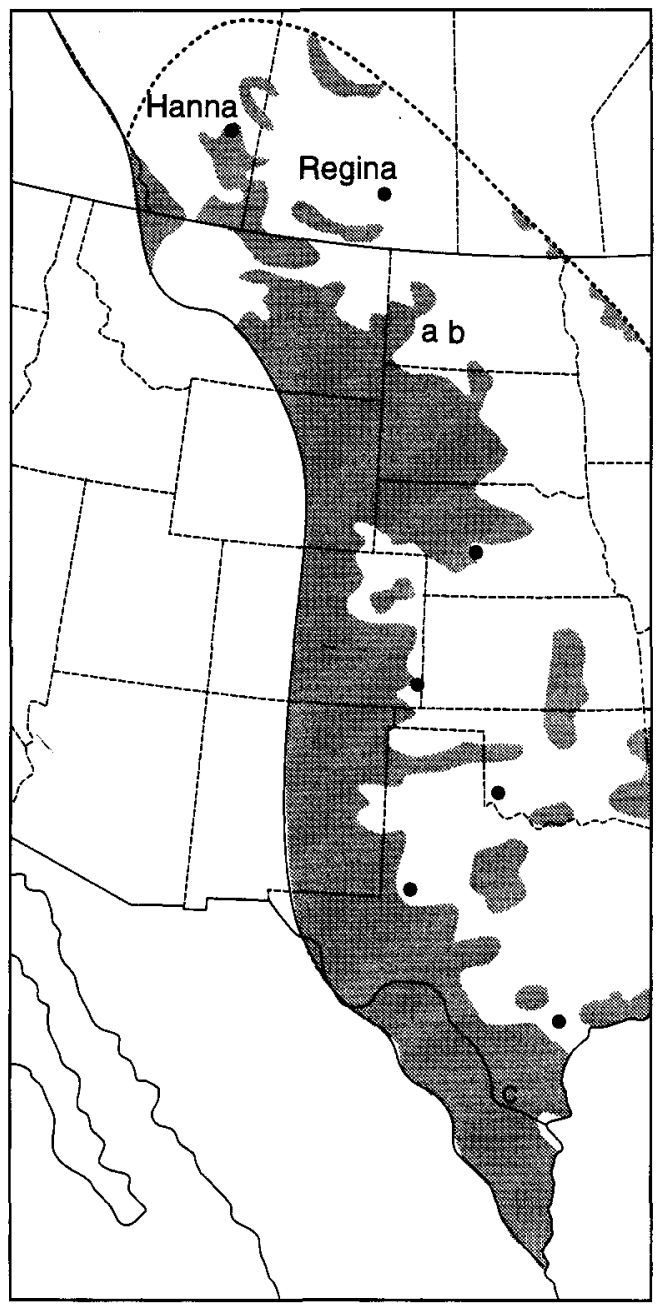

Figure 4. An outline of the Great Plains east of the continental divide and south of the boreal transition zone is shown. Shaded regions reflect land where the dominant land use is grazing of cattle or sheep on rangeland, clear areas within the Great Plains are mainly used for the production of different agricultural crops by various means (Hammond 1982). Dots represent locations where Burrowing Owls, originally banded in Saskatchewan or Manitoba, were recovered dead. Letters represent live owls seen, originally banded in Saskatchewan. The two study areas reported here are located immediately south of Hanna and Regina

loss, restricted dispersal between habitat fragments, predation and collisions with vehicles in one or both of the study areas. Recoveries of ringed owls (Brenkle 1936, James 1992, Helen Trefry pers. comm. 1997) and the monitoring of owls on migration and in winter (Figure 4) suggest that owls frequent the largely cultivated central portion of the Great Plains. Thus, the owls encounter the kinds of altered habitats we describe throughout their annual cycle within 
the Great Plains. In addition to direct habitat alteration in the Great Plains, there are indirect changes that are particularly challenging from a conservation point of view. These include the availability of burrows and the impact of predation mediated through trees that are planted or naturally encroaching on the open plains. One of the owls monitored in winter (Figure $4 \mathrm{c}$ ) was apparently killed by a predator (Larry Ditto and Geoffrey L. Holroyd pers. comm. 1998).

Burrows A strong association between Burrowing Owls and burrows dug by mammals is widely recognized (Coulombe 1971, MacCracken et al. 1985). A partial exception is Florida, where owls dig their own nest burrow or use those of gopher tortoises Gopherus polyphemus and nine-banded armadillos Dasypus novemcinctus (Millsap and Bear 1990). Great Plains owls use culverts (Abbott 1930), junk piles (Grier 1997), or hide in dense vegetation (K.M.C. pers. obs.) when burrows are not available, which confirms the need for sheltering features. This burrow requirement seems so obvious that it is easy to underestimate its importance.

We base our interpretation of the specific roles burrows play on circumstantial observations recalled from approximately 1,000 encounters with families or individual owls by D. Wood (pers. comm. 1998), 1,300 by K.M.C. and 200 by J.K.S. The advantage of a burrow for reproduction seems logical. Utilizing the protection of the burrow, pre-flight juveniles escape into the burrow, as females appear to do only during incubation and early brood rearing. Later, volant juveniles and adults, fly to a nearby burrow when threatened. They nearly always alight on another burrow mound. Circumstances under which Burrowing Owls are regularly away from burrows or burrow mounds include time flying, capturing food on the ground, or roosting on fence posts or similar structures that afford height and visibility. Outside of these circumstances, D.W. and K.M.C. recall only four instances when owls were away from burrows for prolonged periods. In D.W.'s case, an owl flew approximately $500 \mathrm{~m}$ when the nest was approached and returned slowly 'on foot', capturing and eating insects on the way. For the last $15 \mathrm{~m}$, it flew and landed on the home mound. K.M.C. re-located a radio-marked male Burrowing Owl on three occasions over a 4-day period when it was 'roosting' among dense grasses and low shrubs Symphoricarpos and Rosa sp. This individual crouched in deep cover and was flushed only upon close approach (I$2 \mathrm{~m}$ ).

What appears remarkable about the owls so strictly frequenting burrows is that owls capable of flight do not enter the burrow at which they may roost, but, when pressed, repeatedly fly to a nearby burrow instead. On our study areas, this observation is part of local knowledge. Owls have been described as flying out of burrows when approached by livestock or a person on horseback. When approached from a distance, and on windy days, owls tend to crouch low in the burrow entrance with eyes and top of head barely visible. Thus, shelter from wind, the ability to crouch out of sight on sparsely vegetated land, and the enhanced visibility afforded by mounds may be important reasons why owls seek burrows, in addition to protecting eggs and small young. The use Burrowing Owls make of burrows at night is not well known. Owls observed from an observation hide were asleep in daytime with eyes closed while standing on a mound (D. Wood pers. comm. 1998). 
One radio-marked female and her two young took up residence in a pile of discarded wood on the Regina Plains study area, where they stayed for a month (Grier 1997). There were no burrows within $150 \mathrm{~m}$. It is noteworthy that there are apparently no observations of Burrowing Owls using clumps or rows of trees for cover, as some other prairie birds do. K.M.C. saw owls landing out of sight in tall crops only once. Both trees and crops were available on both study areas. It seems reasonable, therefore, to postulate that burrows are an essential feature of Burrowing Owl habitat.

The association between Burrowing Owls and burrows is not limited to the breeding ground. Owls nesting in Canada reside here from April to early October. In both years, we successfully tracked owls through the summer and into early autumn. Only twice was a radio-tagged owl lost without a known fate. Near the end of September and into October owls began to disappear. With the exception of one migrant, these could not be re-located despite extensive aerial searches which often extended $100 \mathrm{~km}$ south of the study area. The timing of these presumed migratory departures was similar between populations (Table 6). Owls tracked during the autumn migration were associated with burrows in Alberta (Clayton 1997), Saskatchewan, and North Dakota (K. M. Clayton unpublished).

The loss of burrows may be detrimental to the owls. Loss of burrows is due to annual-crop production, and the historic and persistent destruction of burrowing mammals, particularly prairie dogs (Miller et al. 1994). At least two professional societies have called for the protection of burrowing mammals as keystone species (Anonymous 1993, Leachman 1994).

Trees and predation Local knowledge, reflecting on changes on the Hanna study area over several decades, indicates that Burrowing Owls have declined substantially in numbers while buteonine hawks have increased. The increase in hawks is related to an increase in trees and shrubs available for nesting (Schmutz et al. 1980, Houston and Bechard 1983), due in part to a reduced incidence of prairie fires. A zone of above average tree availability now extends along a zone of Brown soil developed on sandy loam from Hanna to Sunnynook (Fig. 5). A large fire in 1909 swept over a $150 \times 100 \mathrm{~km}$ area, including the study area (Gordon 1978). A smaller but hot fire in 1975 covered approximately $50 \mathrm{~km}^{2}$ on the study area. Ten years after this fire, the aspen trees had regained their former height.

The Hanna study area is located at the current position of the southward progressing prairie-parkland transition zone. Since settlement by Eurasian descendants, the grassland ecosystem has and continues to change fundamentally. In the past, this ecosystem has been shaped by a combination of drought, large grazers and fire (Archibold and Wilson 1980, Anonymous 1995b, Friedman et al. 1997). It is ironic that J.K.S. had erected artificial nests for buteonine hawks on the Hanna study area in the 1970 (Schmutz et al. 1984). The single-factor management paradigm that informed this project seems flawed in retrospect (Schmutz $1997 \mathrm{~b})$ and underscores the need to focus on the system rather than factors in conservation.

Nests of Burrowing Owls $(n=224)$ near Hanna were recorded on a casual basis from $1975-77,1983-85$ and in 1994 , and more consistently by visiting traditional nests and asking landowners from 1986 to 1993 and 1995 to 1996 . Hawks were 


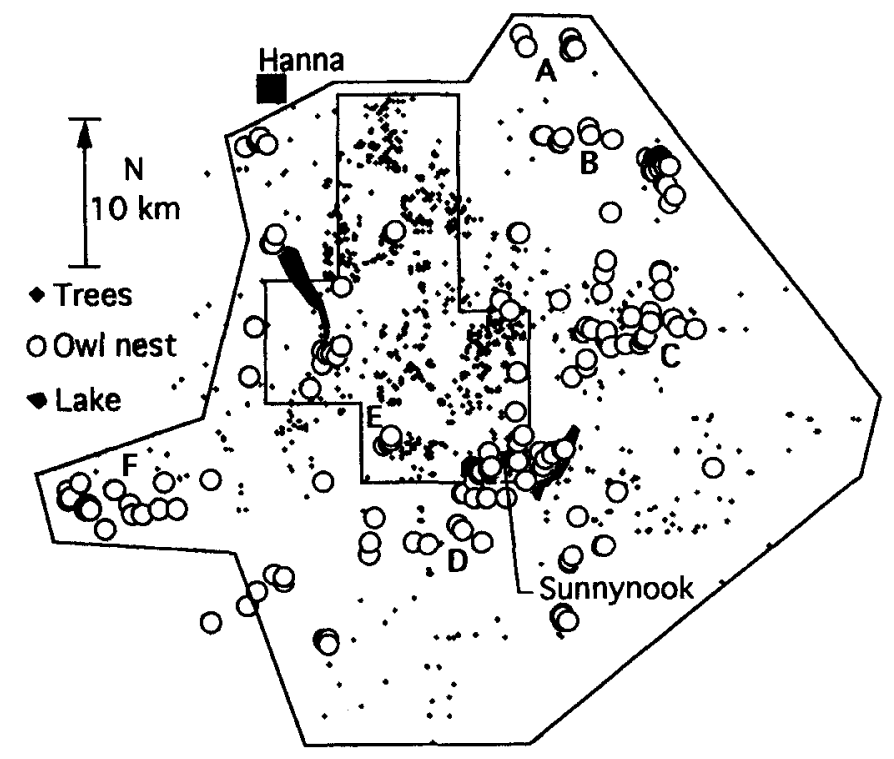

Figure 5. The distribution of nests of owls and hawks and the approximate borders of the $480 \mathrm{~km}^{2}$ hawk study area are shown. The outer line represents the perimeter for which we have reasonably good records of tree distribution. The towns of Hanna and Sunnynook are shown for reference.

monitored throughout all years by intensive searches on a well defined 326$480 \mathrm{~km}^{2}$ study area, and opportunistically in a variable-size perimeter outside of this area (Schmutz and Hungle 1989). The densities of nesting Ferruginous ( $B$. regalis; 9.8-14.0 nests $/ 100 \mathrm{~km}^{2}$ ), Red-tailed (B. jamaicensis; $0.6-4.2$ nests $/ 100 \mathrm{~km}^{2}$ ) and Swainson's Hawks $\left(6.7-21.5\right.$ nests $\left./ 100 \mathrm{~km}^{2}\right)$ recorded on the well-defined study area are among the highest recorded for non-colonial raptors of comparative size (cf. Newton 1979). In addition to the hawk predation on radio-tracked owls cited previously, three additional hawk-related deaths were recorded. One was an adult male owl more than 6 years old, eaten by a raptor, presumably a red-tailed hawk that frequented this area at the time. Two fledglings were dead in Swainson's hawk nests; 2 owls of a total of 159 birds recorded on 2,457 visits to nests. Although this $1.3 \%$ incidence of avian predation during the hawks' nestling period is low, this impact could be significant for a declining owl. An estimated 1o pairs (J.K.S. unpubl. data) of owls on the study area coexist with 82-109 pairs of hawks for 5 months.

We cannot compare precise changes in owl dispersion in relation to hawk distribution because our systematic searches for owls were too limited in time and space. However, the dispersion of nests noted since 1975, does suggest a tendency for owls to frequent sparsely treed portions of the region. Figure 5 shows tree distribution (mainly aspen Populus tremuloides) as evident from all hawk nests recorded over the years (approximately $80 \%$ of all tree clumps). There are some owl nesting areas (clusters A-F) that are notable by their densities and persistence over several years. All except cluster $C$ were located in or at the edge of a sparsely treed area. Cluster $\mathrm{C}$, located in a densely treed area, was the first 
to be reduced to $0-1$ owl per year. Owls in cluster D, at the edge of a sparsely treed area, have persisted for the longest time.

When predation is viewed as a "factor", a logical step is to intervene with a management strategy specifically directed to protecting owls from predators. This, for example, is being done with artificial burrows protecting owl nests from badgers (Wellicome and Haug 1995) in a desperate attempt to protect remnant owl populations. While it is recognized that this method is limited in scale, it is employed to "buy time" for this endangered owl.

When applying a (eco)systems perspective to conservation, our owl predation scenario can be viewed as an outcome in which the forces acting on the owls and the capacity of the owl to respond are changing, conceptually analogous to a "holon" (Allen and Starr 1982). Community dynamics similar to the owl predation we observed have been described as "incidental predation" (Litvaitis and Villafuerte 1996, Sweitzer et al. 1997, Yanes and Suárez 1996), where the impact on a rare species is out of proportion to the energy benefit for the common species. Strategies under a systems perspective might examine the process of predation per se (e.g. its historical development), and its context (e.g. landscape features and human cultural developments).

\section{Owl conservation strategies}

We suggest that the predation by hawks on Burrowing Owls, although basically a rare occurrence, could be a significant factor in owl decline. Considering the Great Plains' ecosystem-wide trend for increasing trees as nest sites and sites from which avian and mammalian predators hunt, coupled with the loss of burrow escape cover, it is easy to envisage the considerable pressure that must be operating on Burrowing Owl populations on their breeding ground, on migration and in winter. Some of these changes seem irreversible.

Past conservation efforts directed largely at the individual owl or site level have not served fully to protect this species, efforts may need to be redirected. We offer the following thoughts on conservation strategies for burrowing owls and their "treeless grassland" ecosystem:

(1) Efforts of conservation on a large-space basis (Jay and Schneider 1994, Rowe 1997) are worthy of vigorous support. Conservation on a patch or single factor basis may fail, especially for broadly distributed and mobile/migratory species such as Burrowing Owls. Such large spaces should include treeless plains. There may be a conservation bias toward treeless plains, which are considered uninspiring by many people. Comparatively more emphasis on the Great Plains seems to be devoted to other landscape features, such as wetlands and riparian habitats (Bond et al. 1992, Knopf and Samson 1994).

(2) If incidental predation and the loss/isolation of escape habitat indeed play a primary role in the owl's decline, these changes are far too pervasive to be affected by owl-level protection measures including endangered species legislation as it is proposed for Canada. Even if this legislation were to include the protection of habitat, the general rather than local nature of ecosystem change severely reduces the effectiveness of protection on a patch-bypatch basis. Many of these sites now occupied by owls are already protected 
or maintained by landowners. Legal mechanisms should focus both on the cultural system (social including economic forces) and the natural system, and use a creative blend of economic and regulatory instruments ("enabling" and punitive legislation). For example, it may be prudent to abandon protection in regions that are already too greatly altered. Instead, major weight (no net loss) should be on the regional protection and/or restoration of the remaining grasslands along with the ecosystem's natural processes (e.g. using fire in land management, reducing human traffic).

(3) With regard to Burrowing Owls, it may be time to prepare Canadians for their probable loss. This process might invite a larger discussion and reflection on the relationship between humans and nature in the twenty-first century. Settlement of the Canadian prairies was only one "wave" altering the landscape. This was followed by the advent of industrial agriculture, then chemical agriculture and recently the arrival of biotechnology and corporatization in agriculture. Depending on the goals Canadians might have $183 \%$ were in favour of protecting declining species in a 1991 questionnaire; Filion et al. 1993), a genuine protection of biodiversity for the distant future may necessitate a reform beyond the micromanipulation of individual factors ("Green Politics"; Merchant 1992). It begs a radical redesign for a sustainable society (Orr 1992), where individuals support conservation not only with advocacy but also purchasing power and similar individual action.

(4) When considering conservation of all lands, compromise may be required with varying degrees of protection. A "fortress" type of strong protection through public or private ownership might be feasible on some land (e.g. "natural areas," but consider Orr 1990, Rowe 1990). Moderate protection over large spaces could be achieved through a traditional ranching economy (Schmutz 1994, Hartnett et al. 1997, Page 1997). Dixon (1998) provides examples of how bird conservation has been, or could be, advanced by affecting changes within a production system, such as farming in Europe.

(5) Burrowing Owl conservation represents a challenge not only for Canada, but, as a migratory species, it represents an international dilemma. A promising strategy might include a patchwork of strategically chosen reserves (Johns and Soule 1995) coupled with sustainable land uses in surrounding buffer areas. It may be increasingly apparent that a human quality of life and functioning ecosystems face similar root threats. The best solutions may be those inclusive solutions that meet diverse goals.

\section{Acknowledgements}

Funding for this project was kindly provided by the Alberta Sports, Recreation, Parks and Wildlife Foundation, the Endangered Species Recovery Fund co-sponsored by the World Wildlife Fund Canada and the Canadian Wildlife Service of Environment Canada, Margaret K. Goodman, TransCanada Pipelines, TransGas, Interprovincial Pipelines Inc. and Foothills Pipe Lines. Logistical support was provided by the Special Areas Board of Hanna, and Greg and Karen Gordon. Doug Grier and Sherwyn Solomon provided assistance and companionship in the field. Figure 2 was kindly prepared by Kim Hodge and Cam Kenny, Prairie Farm Rehabilitation Administration. Many others loaned equipment and provided advice. 


\section{References}

Abbott, C. G. (1930) Urban burrowing owls. Auk 47: 564-565.

Allen, T. F. H. and Starr, T. B. (1982) Hierarchy: perspectives for ecological complexity. Chicago: University of Chicago Press,

Anonymous. (1988) Prairie conservation action plan (map). Toronto: World Wildlife Fund Canada.

Anonymous. (1993) 1992 Annual meeting. J. Raptor Res. 27: 51-52.

Anonymous. (1995a) Canadian biodiversity strategy: Canada's response to the Convention on Biological Diversity. Ottawa: Minister of Supply and Services Canada

Anonymous. (1995b) Bison disappearance linked to expansion of aspen parkland. Impact: Canadian forests and climate change, No. 5: 1 and 3.

Archibold, O. W. and Wilson, M. R. (1980) The natural vegetation of Saskatchewan prior to agricultural settlement. Can. J. Bot. 58: 2031-2042.

Bloom, P. H. (1987) Capturing and handling raptors. Pp. 99-123 in B. A. G. Pendleton, B. A. Millsap, K. W. Cline and D. M. Bird, eds. Raptor management techniques manual. Baltimore: National Wildlife Federation.

Bock, C. E., Bock, J. H., Kenney, W. R. and Hawthorne, V. M. (1984) Responses of birds, rodents, and vegetation to livestock exclosure in a semidesert grassland site. J. Range ilanage. 37: 239-242.

Bond, W. K., Cox, K. W., Heberlein, Manning, T. E. W., Witty, D. R. and Young, D. A. (1992) Wetland evaluation guide: final report of the Wetlands are not Wastelands Project. Paper No 1992-1. Ottawa, Canada: North American Wetlands Conservation Council

Brenkle, J. F. 1936. The migration of the western burrowing owl. Bird-Banding 7: 166-168.

Brooks, B. L. and Temple, S. A.. (1990) Dynamics of a loggerhead shrike population in Minnesota. Wilson Bull. 102: 441-450.

Byers, C. R. and Steinhorst, R. K. (1984) Clarification of a technique for analysis of utilization-availability data. J. Wildl. Manage. 48: 1050-1053.

Caughley, G. (1977) Analysis of vertebrate populations. Toronto: Wiley.

Clayton, K. M. (1997) Post-fledging ecology of Burrowing Owls in Alberta and Saskatchewan: their dispersal, survival, habitat use and diet. Saskatoon, Canada: M.Sc. thesis, University of Saskatchewan.

Coulombe, N. H. (1971) Behaviour and population ecology of the Burrowing Owl, Speotyto cunicularia, in the Imperial Valley of California. Condor 73: 162-176.

Doak, D. F., Marino, P. C. and Kareiva, P. M. (1992) Spatial scale mediates the influence of habitat fragmentation on dispersal success: implications for conservation. Theoret. Pop. Biol. 41: 315-336.

Dixon, J. (1998) Feeding the World and protecting our birds: are the two compatible? Bird Conserv. Intern. 8: 113-118.

Einarsen, A. S. (1956) Determination of some predator species by field signs. Oregon State Monogr.10: 1-34.

Filion, F. L., DuWors, E. P., Boxall, P., Bouchard, P., Reid, R., Gray, P. A., Bath, A., Jacquemot A. and Legare, G.. (1993) The importance of wildlife to Canadians: highlights of the 1991 survey. Ottawa: Environment Canada, Supplies and Services.

Foster, C. C., Forsman, E. D., Meslow, E. C., Miller, G. S., Reid, J. A., Wagner, F. F., Carey, A. B. and Lint, J. B. (1992) Survival and reproduction of radio-marked adult spotted owls. J. Wildl. Manage 56: 91-95.

Fox, G. A., Mineau, P., Collins, B. and James, P. C. (1989) The impact of the insecticide carbofuran (Furadan $480 F$ ) on the burrowing owl in Canada. Ottawa: Canadian Wildlife Service (Technical Report 72).

Friedman, J. M., Scott, M. L. and Auble, G. T. (1997) Water Management and cottonwood forest dynamics along prairie streams. Pp. 49-71 in F.L. Knopf and F.B. Samson, eds. Ecology and conservation of Great Plains vertebrates, New York: Springer-Verlag. 
Frumkin, R. (1994) Intraspecific brood-parasitism and dispersal in fledgling sparrowhawks Accipiter nisus. Ibis 136: 426-433.

Gordon, A. (1978) Roads to Rose Lynn: A history of the Rose Lynn, Halladay, Sheerness, Stanmore, Scotfield, Richdale and Berry Creek areas. Edmonton, Canada: Inter-Collegiate Press.

Gorman, J. (1988) A land reclaimed: the story of Alberta's Special Areas. Hanna, Canada: Gorman and Gorman.

Grier, D. A. (1997) Scrap-lumber roost used by Burrowing Owls (Speotyto cunicularia). J. Raptor Res. 31: 391.

Hamerstrom, F. (1972) Birds of prey of Wisconsin. Madison: Wisconsin Society for Ornitho$\log$.

Hammond Inc. (1982) Medallion World atlas. Maplewood: Hammond Inc.

Hartnett, D. C., Steuter, A. A. and Hickman, K. R. (1997) Comparative ecology of native and introduced ungulates. Pp. 72-101 in F. L. Knopf and F. B. Samson, eds. Ecology and conservation of Great Plains vertebrates. New York: Springer-Verlag.

Haug, E. A., and Oliphant, L. W. (1990) Movements, activity patterns, and habitat use of burrowing owls in Saskatchewan. J. Wildl. Manage. 54: 27-35.

Haug, E. A., Millsap, B. A. and Martell, M. S.. 1993. Burrowing owl (Speotyto cunicularia). No. 61 in A. Poole and F. Gill, eds., The birds of North America. Washington, D.C.: American Ornithologists Union.

Heisey, D. M. and Fuller, T. K. (1985) Evaluation of survival and cause-specific mortality rates using telemetry data. J. Wildl. Manage. 49: 668-674.

Hjertaas, D. G. (1997) Operation Burrowing Owl in Saskatchewan. J. Raptor Res. Report 9: 112-116.

Houston, C. S. and Bechard, M. J. (1983) Trees and the red-tailed hawk in southern Saskatchewan. Blue Jay 14: 99-109.

James, P. C. (1992) Where do Canadian Burrowing Owls spend the winter? Blue Jay 50: 93-95.

James, P. C. and Fox, G. A. (1987) Effects of some insecticides on productivity of Burrowing Owls. Blue Jay 45: 65-71.

James, P. C., Ethier, T. J. and Toutloff, M. K. (1997) Parameters of a declining Burrowing Owl population in Saskatchewan. J. Raptor Res. Report 9: 34-37.

James, P. C., Fox, G. A. and Ethier, T. J. (1990) Is the operational use of strychnine to control ground squirrels detrimental to Burrowing Owls? J. Raptor Res. 24: 120-123.

Jay, J. J. and Schneider, E. (1994) Embracing complexity: the challenge of the ecosystem approach. Alternatives 20: 32-39.

Johns, D. and Soulé, M. (1995) Getting from here to there: an outline of the wildlands reserve design process. Wild Earth 5(4): 32-36.

Kenward, R. E. (1987) Wildlife radio-tagging. San Diego: Academic Press.

King, R. A. (1996) Post-fledging dispersal and behavioural ecology of Burrowing Owls in southwestern Idaho. Boise, U.S.A.: M.S. thesis, State University.

Knapp, P. A. (1996) Cheatgrass (Bromus tectorum L.) dominance in the Great Basin Desert. Global Environ Change 6: 37-52.

Knopf, F. L. and Samson, F. B. (1994) Scale perspectives on avian diversity in western riparian ecosystems. Conserv. Biol. 8: 669-676.

Leachman, B. (1994) Conservation of prairie dog ecosystems in the United States of America. Soc. Conserv. Biol. Newsletter 1(2): 7.

Lens, L. and Dhondt, A. A. (1994) Effects of habitat fragmentation on the timing of Crested Tit (Parus cristatus) natal dispersal. Ibis 136: $147-152$.

Ligon, J. D. (1963) Breeding range expansion of the burrowing owl in Florida. Auk 80: $367-368$.

Litvaitis, J. A. and Villafuerte, R. (1996) Intraguild predation, mesopredator release and prey stability. Conserv. Biol. 10: 676-677. 
MacCracken, J. G., Uresk, D. W. and Hansen, R. M. (1985) Vegetation and soils of burrowing owl nest sites in Conata Basin, South Dakota. Condor 87: 152-154.

Marcum, C. L. and Loftsgaarden, D. O.. (1980) A nonmapping technique for studying habitat preferences. J. Wildl. Manage. 44: 963-968.

Merchant, C. (1992) Radical ecology: the search for a livable World. New York: Routledge, Chapman and Hall.

Miller, B., Ceballos, G. and Reading, R. (1994) The prairie dog and biotic diversity. Conserv. Biol. 8: 677-681.

Millsap, B. A. and Bear, C. (1990) Double-brooding by Florida Burrowing Owls. Wilson Bull. 102: 313-317.

Newton, I. (1979) Population ecology of raptors. Vermilion, U.S.A.: Buteo Books.

Orr, D. W. (1990) The question of management. Conserv. Biol. 4: 8-9.

Orr, D. W. (1992) Ecological literacy: education and the transition to a postmodern World. Albany: State University of New York Press.

Page, J. (1997) Ranchers form a 'radical center' to protect wide-open spaces. Smithsonian 28(3): 50-56, 58 and 60-61.

Pasitschniak-Arts, M. and Messier, F. (1996) Predation on artificial duck nests in a fragmented prairie landscape. Ecoscience 3: 436-441.

Robel, R. J., Briggs, J. N., Dayton, A. D. and Hulbert, L. C. (1970) Relationships between visual obstruction measurements and weight of grassland vegetation. J. Wildl. Manage. 23: 295-297.

Rowe, J. S. (1990) Home Place: essays on ecology. Edmonton: NeWest Publishers.

Rowe, J. S. (1997) The necessity of protecting ecoscapes. Global Biodivers. 7(2): 9-12.

Schmutz, J. K. (1994) Endangered prairie birds and the range cow: opportunities for cooperation. Pp. $270-276$ in F. K. Taha, Z. Abouguendia and P. R. Horton, eds. Managing Canadian rangelands for sustainability and profitability. Regina, Canada: Grazing and Pasture Technology Program.

Schmutz, J. K. (1997a) Selected microhabitat variables near nests of burrowing owls compared to unoccupied sites in Alberta. J. Raptor Res. Report 9: 80-83.

Schmutz, J. K. (1997b) Evolving attitudes and approaches in conservation biology. Pp. 103-107 in P. Jonker, J. Vandall, L. Baschak and D. Gauthier, eds. Caring for Home Place: protected areas and landscape ecology. Saskatoon: University Extension Press.

Schmutz, J. K. and Hungle, D. J. (1989) Populations of Ferruginous and Swainson's Hawks increase in synchrony with ground squirrels. Can. J. Zool. 67: 2596-2601.

Schmutz, J. K., Fyfe, R. W., Moore, D.A. and Smith, A. R. (1984) Artificial nests for Ferruginous and Swainson's Hawks. J. Wildl. Manage. 48: 1009-1013.

Schmutz, J. K., Schmutz, S. M. and Boag, D. A. (1980) Coexistence of three species of hawks (Buteo spp.) in the prairie-parkland ecotone. Can. J. Zool. 58: 1075-1089.

Schmutz, J. K., Wood, G. and Wood, D. (1991) Spring and summer prey of Burrowing Owls in Alberta. Blue Jay 49: 93-97.

Smoliak, S., Willms, W. D., Wroe, R. A., Adams, B. W. and Ehlert, G. (1988) Range pastures in Alberta. Edmonton: Alberta Agriculture.

Strong, W. L. and Leggat, K. R. (1992) Ecoregions of Alberta. Edmonton: Alberta Forestry, Lands and Wildlife.

Sweitzer, R. A., Jenkins, S. H. and Berger, J. (1997) Near-extinction of porcupines by mountain lions and consequences of ecosystem change in the Great Basin Desert. Conserv. Biol. 11: 1407-1417.

Warnock, R. 1997. Is habitat fragmentation a factor in the decline of the Burrowing Owl in Saskatchewan? Blue Jay 55: 222-228.

Wedgwood, J. A. (1978) The status of the burrowing owl in Canada. Ottawa: Committee on the Status of Endangered Wildlife in Canada. 
Wellicome, T. I. and Haug, E. A. (1995) Updated report on the status of the burrowing owl in Canada. Ottawa: Committee on the Status of Endangered Wildlife in Canada.

White, G. C. and Garrott, R. A. (1990) Analysis of wildlife radio-tracking data. San Diego: Academic Press.

Wroe, R. A., Smoliak, S., Adams, B. W., Willms, W. D. and Anderson, M. L. (1988) Guide to range condition and stocking rates for Alberta grasslands. Edmonton: Alberta Forestry, Lands and Wildlife.

Yanes, M. and Suárez, F. (1996) Incidental nest predation and lark conservation in an Iberian semiarid shrubsteppe. Conserv. Biol. 10: 881-887.

\section{KORT M. CLAYTON}

Department of Biology, University of Saskatchewan, 112 Science Place, Saskatoon, $S K S_{7} N{ }_{5} E_{2}$, Canada (Current address: Powder River Eagle Studies, P.O. Box 2411, Gillette, Wyoming, 82717, U.S.A.). E-mail: clayton@vcn.com

\section{JOSEF K. SCHMUTZ}

Department of Biology, University of Saskatchewan, 112 Science Place, Saskatoon, $S_{K} S_{7} N_{5} E_{2}$, Canada. Current Address: Centre for Studies in Agriculture, Law and the Environment, University of Saskatchewan, 51 Campus Drive, Saskatoon, $S K S_{7} N$ 5A8, Canada) 